\title{
Improving Students Learning Motivation Through Innovation of Media Learning in Physical Education for Visual Impairment
}

\author{
Febriana Pratiwi ${ }^{1 *}$, EgaTrisna Rahayu ${ }^{2}$ \\ ${ }^{1}$ Department of Sports Education, Universitas Pendidikan Indonesia, Indonesia \\ ${ }^{2}$ Department of Physical Education, Universitas Singaperbangsa Karawang, Indonesia \\ *Corresponding author. Email: ${ }^{1}$ febrianapratiwi@upi.edu
}

\begin{abstract}
The purpose of this study is to identify and analyze the motivation of learning in children with visual impairment through the application of innovative learning media through sound ball in physical education. This is an experimental reseacrh method using a One Group Pretest-Posttest design. Treatment is done at WiyataGuna special needs school in Bandung City, Indonesia. The number of samples in this study were 17 students consisting of 10 male students and 7 female students. The instrument is a questionnaire consisting of 27 items adopted from Motivation Strategies for Learning Questionnaire(MSLQ). Data were analysed using t-test. Result of the posttest showeds a significant influence on students motivation by applying innovation of sound ball learning media in physical education $(\mathrm{p}<0.05)$. As a conclusion, innovation of sound ball learning media is highly recommended for teachers of physical education to improve learning motivation in children with special needs, so that the learning objectives of physical education can be achieved optimally.
\end{abstract}

Keywords: Visual Impairment, Motivation, Physical Education, Sound Ball.

\section{INTRODUCTION}

Physical guidance is one part of improving human quality. In connection with this, physical education is required to be directed to form a healthy body and mental well, in order to produce a productive human. Physical growth is a process of physical change that is in line with the increasing age of a person. That growth allows the development of cognitive, affective, and psychomotor spheres. One of the main reasons young people participate in physical activity and sports is for the sheer pleasure they experience while moving and interacting with their peers. Young people have an innate desire to be active, and it is the responsibility of physical education specialists to fulfill this desire. The concept of promoting intrinsic motivation, "the motivation to engage in activity for pleasure and mere satisfaction is often examined in the context of physical education" [1]. Experts agree that children who are intrinsically motivated are more likely to experience their physical activity as positive, bringing them closer to physically active lifestyles [2].

Motivation is seen as a mental impulse that moves and directs human behavior, including learning behavior. In the motivation contained the desire that activates, moves, distributes and directs attitudes and behaviors of individual learning [3]. The first potential barrier to motivation relates to students' intrinsic motivation. Problems arise in the uniqueness of each individual because what motivates one student to learn may not motivate others. Therefore, the involvement of some students in performing the task of motion due to unpleasant tasks, less interesting learning media and create intrinsic motivation to participate lost. Students who are intrinsically motivated to engage in activities for fun or challenge. External benefits and rewards are not needed to encourage motivatio [4]. Increased motivation is very necessary for students in the learning process of physical education. High motivation encourages students to be diligent in practicing, diligent and eager to do the exercises. So with high motivation owned by the students, can support better learning achievement also. Vice versa if student motivation is low then the spirit of learning will decrease and the learning outcomes are questionable. This can be done by teachers, especially in how to provide motivated psychological encouragement.

Learning physical education will run less well if the teacher uses only facilities and infrastructure that is unimpeded without any creativity done, whereas the use of good and appropriate means will facilitate the achievement of learning objectives. By using the means of learning or tool then the students will more easily accept and understand the material presented by the teacher. Especially for children with special needs (ABK), ABK classified in several types, one type of children with special needs of students with visual impairment. The blind itself is divided into three classifications: total blindness, visual impairment, and low vision.

Visual impairment is essentially a condition of the eyes or the sense of sight that because something is not working properly, so that it has limited and / or the inability to see. 
For young people, visual impairment poses a risk of diminished participation and social exclusion. They face challenges in various areas of their lives. Young people with disabilities often experience childhood longer than their peers, for example, are too protective of their parents and helpers, lack of tools, or the nature of their disability (Ahponen, 2008). Blind students generally have constraints on motor development. Especially for visual impairment students who lose sight from an early age. The more limited the view, the more constrained also motor development. Visual impairment students also tend to have poor posture. This is because they often bend and grope the object in front of it. So that their ability in terms of running and throwing becomes less good as well. According to Yosfan Azwandi (2007: 122) argued that people who experience visual impairment or visual impairment they do not have visual perception, so to understand everything they hang everything on the other senses, especially on the sense of hearing, touch and smell.

Motor learning for visual impairment students is very important. As far as possible physical education education in students visual impairment can improve the quality of motor development students visual impairment. The use of appropriate learning tools will be helpful and motivate them to keep learning. One of the trigger factors of student motivation, especially for crew especially visual impairment that is through modification or innovation in learning media. The appropriate learning media for students with special needs will greatly facilitate the achievement of physical education learning goals. The most important thing is that the successful outcome of physical skills learning is creating an environment where students are encouraged and motivated to experience various forms of movement.

One of the learning media that is often used by visual impairment students is in the form of a sound ball. Innovation of learning media in the form of a sound ball for visual impairment students still need to be developed to help improve student's motivation of visual impairment in doing physical activity. Sound ball is often used by students visual impairment is a ball in which is given a sound that comes from bells or sand. But the sound generated from the ball is still very limited, the new ball will sound or make a sound when the ball is in a state driven. If the ball is still or without movement then the ball will not sound. Limitations of sounds issued by the ball can hinder the independence and motivation of students visual impairment in playing ball. If in playing the ball students visual impairment is still dependent with others or people beware, it can reduce the independence and motivation to play in the student visual impairment. Therefore a solution is needed to make a special ball for visual impairment students who can still sound consistently even if the ball is in a stationary or unmoved position, combining the use of technology will support the teacher's goal to motivate all students in physical education (Mowling, Eiler, Brock, \& Rudisill, 2004) so as to foster students' visual impairment motivation to move or play with the ball.
The purpose of this article is to identify and analyze the constant use of the ball in the learning of physical education for students of visual impairment to improve their learning motivation.

\section{METHOD}

The method used to reveal the problem in this research is experimental method. Experimental studies are research conducted through experimentation or experimentation. Experimentation shows a deliberate attempt to modify the conditions that determine the occurrence of an event, as well as the observation and interpretation of changes occurring in that event which is done in a controlled manner. In this research there is a treatment (treatmen) that is by applying the innovation of voiced ball learning media in physical education applied to certain groups within a certain period of time, then seen its development

The research design used is One Group Pretest-Posttest design. In this design there is no control group, and the subject is not placed randomly, the advantages of this design are done pretest and posttest so it can be known with certainty result difference given treatment (Maksum, 2009: 47-48). Treatment given as many as 8 times meeting to 17 students SDLB Wiyata Guna which has visual impairment barriers. With tratmen using innovative voicelearning media ball in the learning of physical education. The treatment procedure has been compiled in a predesigned learning scenario.

The population is a group of individuals in an area or environment to be studied. Meanwhile, according to population is the entire individual or object that is intended to be examined and will be subject to generalization. Population is important in doing research because the target is used to obtain data and information in research. Population used in this research is visual impairment student SLBA Wiyata Guna Bandung with participants as many as 17 students (10 male students, and 7 female students).

The research procedure is: (1) Conducting preliminary observation by interviewing with physical education teacher in SDLB Wiyata Guna Bandung to obtain information about: (a) implementation of instructional done by teacher in physical education education to student visual impairment, (b) ) obstacles encountered in implementing the application of physical education learning and how to overcome them, and (c) data review as literature study; (2) Agreeing the implementation of learning with the teacher, namely the implementation of innovative learning media in the ball sound in physical education on students visual impairment. In this study, teachers carry out the process of learning, while the author acts as an observer and a teacher partner. Furthermore, the learning is carried out according to the planned schedule; (3) Planning, ie preparing a research plan, covering the necessary capabilities in conducting the research, the formulation to be achieved in accordance with the research, and the design or the research steps; (4) Conducting instrument test, that is by requesting the consideration of the instrument used in consultation with 
expert judgment to consider the instrument whether it is feasible to use or not; (5) Giving pretest of student learning motivation of visual impairment in experiment class; (6) Introducing innovative voice-learning media in the learning of physical education of students with visual impairment by providing training or explanation of the steps and how to implement it to the teacher; (7) Provision of treatment (treatment) to the experimental class by using the innovation of voice-learning ball media; (8) Provide posttest of learning motivation of visual impairment student in experimental class after being treated; (9) Using a different test after previously tested the normality and homogeneity of existing data variables to test whether differences in student learning motivation between pretest and posttest results are significant or only occur by chance alone; (10) Conducting analysis of research data; and (11) Draw the conclusion of the research results.

Further instruments or tools used in data collection. The instrument used to measure students' motivational skills is a questionnaire instrument based on the questionnaire Motivation Strategies for Learning Questionnaire (MSLQ) developed. This questionnaire consists of 27 statement points which are the elaboration of a statement containing 4 Intrinsic Goal Orientation, 3 Extrinsic Goal Orientation statements, 4 Task Value statements, 3 Control of Learning Belief statements, 8 Self-Efficiency for Learning \& Performance statements, 5 questions Anxiety Test. This questionnaire uses Likert scale with 4 assessment criteria, that is 1 if the respondent strongly disagrees with the statement, score 2 if the respondent does not agree to the statement, score 3 if the respondent agree with the statement, the score of 4 respondents strongly agree with the statement.

Technique Data analysis is done by steps: (1) data entry research; (2) descriptive data analysis; (3) requirements analysis test; (4) hypothesis test.

\section{RESULTS}

The result of filling the questionnaire of student learning motivation of visual impairment of SLBA Wiyata in Bandung before using ball of sound in learning of physical education (pre-test) yielded average amount of 91,58, standard deviation 2,075, 4,324 variant. Result of filling questionnaire student learning motivation visual impairment SLBA Wiyata Guna Kota Bandung after using ball sound in learning of physical education (post-test) yielded average equal to 98,56 , standard deviation equal to 1,647 with variant 2,343 .

Table 2 shows the lowest and highest values in preand post-deployment of ball-sounding media against motivation.

Results of students' learning motivation visual impairment SLBA Wiyata Guna Bandung before using ball sounds in learning physical education (pre-test) resulted in the lowest value of 87 and the highest score 93. After being treated through the application of ball sound (post-test) 96 and the highest score of 99 .

Table 3 shows the change in motivation of the results from the pre-test to the post-test of the difference of mean, standard deviation and variance and the lowest and highest value.

The change of motivation from pre-test to post-test is an average of 8 and a standard deviation of -0.546 with a variant change of -2 , as well as the highest and lowest values of 7 and 8 respectively. From the result it can be said that the application of the ball sound in learning physical education can improve students' learning motivation visual impairment SLBA Wiyata Guna Bandung for $8.72 \%$.

Table 4 shows a change in student learning motivation through the results of the $t$ test of the sampled t-shaped (two tailed $\mathrm{t}$ test)

There is a change in post-test results that are better than pre-test on learning motivation in accordance with the results of paired sample $\mathrm{t}$ test, with $\mathrm{t}$ arithmetic greater than $t$ table $(13,756>2,879)$. So in other words, it can be concluded that there is a significant influence on the innovation of learning media in the sound ball in improving the students' learning motivation visual impairment impairment SLBA Wiyata Guna Bandung.

The main purpose of this study was to explore the effects of the application of ball-sounding media consistent to motivation in children with visual impairment, because children with visual impairment had a poorer quality of object control than the children seen [5]. The application of the use of ball in the voice of education in physical education is done in SLBA Wiyata Guna Bandung. "Physical education learning has a role in providing opportunities for students to be directly involved in various learning experiences, this is important because of its impact on children's development, education, and quality of life" [6]. Through physical and sports activities undertaken systematically. Teachers must be able to motivate and motivate students to want to study more actively to achieve higher achievement. Motivation is a condition or an internal status that directs a person's behavior to actively act in order to achieve a goal [7]. For that teachers need to try to understand the condition and character of each student in order to be able to find the appropriate form of motivation for students. As a good motivator, physical education teachers must understand the three keys to motivating students to practice. The three key motivating students to practice are as follows: 1) Success oriented, that is, the physical education teacher must be able to create and change the form of skilled learning activities capable of encouraging students to adjust their skill level with the level of ability, able to make students happy to do learning activities; 2) Intrinsic motivation, physical education teachers should be able to encourage students to work hard so that students get satisfaction from the achievement of learning achievement; 3) In accordance with the level of development, physical education teachers should be able to create learning activities that can reflect different levels of ability and age of students, thus encouraging students to work hard and students remain active in carrying out learning activities [8]. This is where the teacher needs to apply learning media innovation in accordance with the characteristics of the students. Through the innovation of learning media ball in the 
learning of the ball is expected to get students movement activities that can cause a sense of fun, joy and freedom so that students are more motivated towards learning. In addition, the objectives of learning are expected to be achieved and changes in behavior of students.

Ball sound in question is a learning medium that provides pleasure for students with visual impairment, because when the ball used to have a consistent sound, the students will remain active and eager in the implementation of learning. The sound contained in the ball can be adjusted to the circumstances and situations, so it can be done anywhere. Speech-ball innovations need to pay attention to the feasibility of using in accordance with the visual impairment characteristic of this ball should be light, brightly colored, and equipped with sound components that can sound consistently even when the ball is still.

In this lesson, pleasure is the ultimate key that strongly supports student visual impairment games. Therefore, students who can feel happy with the ball in the voice of learning physical education will greatly help these students are motivated in learning. Speech-ball innovations help to attract children and improve attitudes toward the task of motion provided by the teacher. They become more critical of the completion of their own motion tasks and others, their understanding and appreciation grow. A manifestation of this lies in the fact that ball soccer media is consistent for children with visual impairment making among them motivate each other. With the experience and consideration of these related practices, it is possible to provide ballot ball innovations for physical education programs for blind students throughout the education level.

\section{CONCLUSION}

Innovation of voiced ball learning media becomes a provider of tools and support to enhance learning motivation and expand the opportunity to participate in physical activity for visual impairment. Innovative voicelearning media innovation is determined primarily to enable people with visual impairment to have the motivation to participate and enjoy team sports activities while considering their unique needs. Sports activities that make the ball as a tool in games such as baseball and football greatly enhance the individual's emotional, physical and personal development with visual impairment. Student participation in visual impairment in physical activity not only reduces individual health risks such as obesity, but improves overall quality of life by promoting mutually motivating friendships.

From the result and discussion in this research, hence given the suggestion so that the result of this research can be really useful, that is with the result of the research hence the application of the use of innovation of voice ball learning media is used as a references for physical education teacher in an effort to increase student's learning motivation in process learning especially learning physical education. Innovation of learning media ball in the learning process is not only used for physical education only but also can be used in everyday sports activities. In order to get maximum results especially in learning by applying the use of innovative learning media in the sound ball in improving students' visual impairment motivation visual impairment SLBA Wiyata Guna Bandung, the application of learning media innovation should be tailored to the ability and condition of students so that students can follow the learning process freely, happy and not afraid of injury and can change behavior to a better direction.

\section{ACKNOWLEDGMENT}

The author would like to thank all participants in this research. The research was conducted as part of a project funded by the Ministry of Research, Technology and Higher Education of the Republic of Indonesia.

\section{REFERENCES}

[1] Biddle, S. J. H, "Enhancing motivation in physical education," In G. C. Roberts (Ed.), "Advances in motivation in sport and exercise," (2nd ed., pp. 101-127). Champaign, IL: Human Kinetics. 2001

[2] Weiss, M. R, "Motivating kids in physical activity," The President's Council; on Physical Fitness and Sports Research Digest, 3(11), 1-8. 2000

[3] Papaioannou, A, "Students' perceptions of the physical education class environment for boys and girls and the perceived motivational climate," Research Quarterly for Exercise and Sport, 69(3), 267-275. 1998.

[4] Kilpatrick, M., Hebert, E., \& Jacobsen, D, "Physical activity mo- tivation: A practitioner's guide to self-determination theor," J. of Physical Education; Recreation \& Dance. 73(4), 36-41. 2002.

[5] Houwen, S., Visscher, C., Hartman, E., \& Lemmink, K. A. P. M. (n.d.), "Gross Motor Skills and Sports Participation of Children," J. Of, pp, 37-41. May. 2013.

[6] Shrestha, J. B., Gnyawali, S., \& Upadhyay, M. P, "Causes of blindness and visual impairment among students in integrated schools for the blind in Nepal," J. Of Ophthalmic Epidemiology, 19(6), pp, 401-406. May. 2012.

[7] Carver, M., \& Colestock, C, "Motivation of Child Interest," https://doi.org/10.1080/23267240.1933.10623481, pp, 37-41. Jan. 2013.

[8] Suherman, Adang, "Revitalisasi Pengajaran dalam Pendidikan Jasmani," Bandung; CV Bintang Warli Artika. 2009. 